\title{
A RARE CAUSE OF HOARSENESS OF VOICE
}

\section{Chetana Panabaka ${ }^{1}$, M. Krishnakanth², Mahalakshmi V³, Anandan S4, Sudha R ${ }^{5}$}

\section{HOW TO CITE THIS ARTICLE:}

Chetana Panabaka, M. Krishnakanth, Mahalakshmi V, Anandan S, Sudha R. "A Rare Cause of Hoarseness of Voice". Journal of Evolution of Medical and Dental Sciences 2014; Vol. 3, Issue 47, September 25;

Page: 11454-11456, DOI: 10.14260/jemds/2014/3498

ABSTRACT: A 19 years old male with characteristic skin features of Lipoid Proteinosis along with lingual and laryngeal involvement is presented herewith.

KEYWORDS: Lipoid proteinosis, Hoarseness of voice.

INTRODUCTION: Lipoid proteinosis, also known as Urbach-Wie the disease is a very rare, autosomal recessive disorder, characterized by infiltration of hyaline material into the skin, oral cavity, larynx and internal organs. ${ }^{1}$ There are only about 300 LP cases that have been reported in the literature. ${ }^{2}$

CASE REPORT: A 19 yrs old male came to our skin OPD with complaints of raised skin lesions over the face, neck, upper limbs, abdomen, lower limbs since 7 months of age and change in voice since infancy with worsening of hoarseness of voice for 2 months and premature greying of hair for a year. There was no history of itching, photosensitivity, abdominal pain, headache, seizures, memory loss, epilepsy, difficulty in swallowing or breathing or protruding the tongue. There was no parental consanguinity. He gave history of similar complaints in paternal uncle.

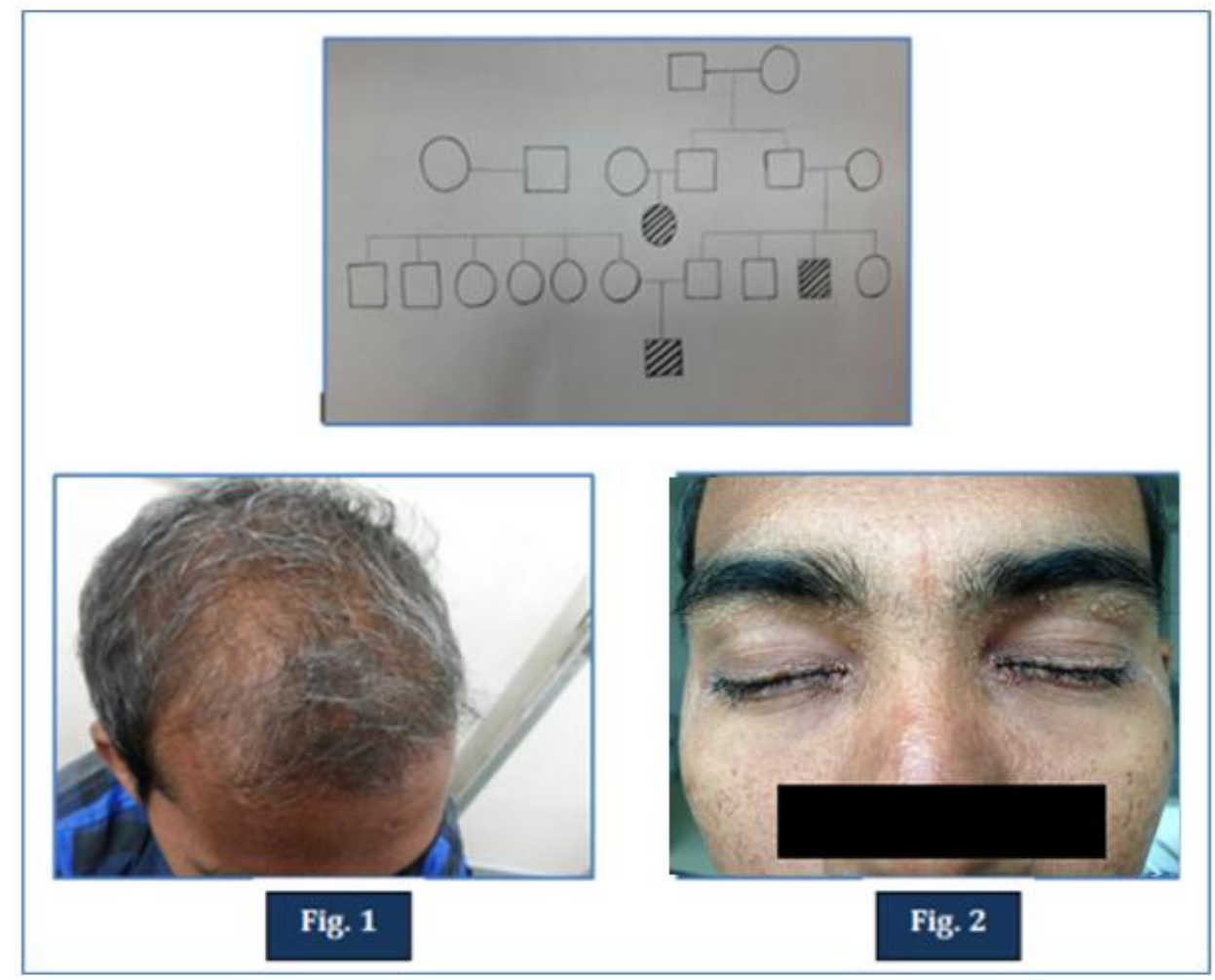


Clinical examination revealed hoarseness of voice, woody tongue on palpation with no restricted tongue movements. Scalp showed patchy alopecia (Figure 1).Numerous skin coloured papules and warty plaques (Figure 3) were present over the forehead, neck, both upper and lower limbs. The characteristic moniliform blepharosis (Figure 2) was present over bilateral upper and lower eyelids. Pock-like scars were present on both cheeks. Systemic examination like cardiovascular, respiratory, central nervous system, ophthalmologic was normal.

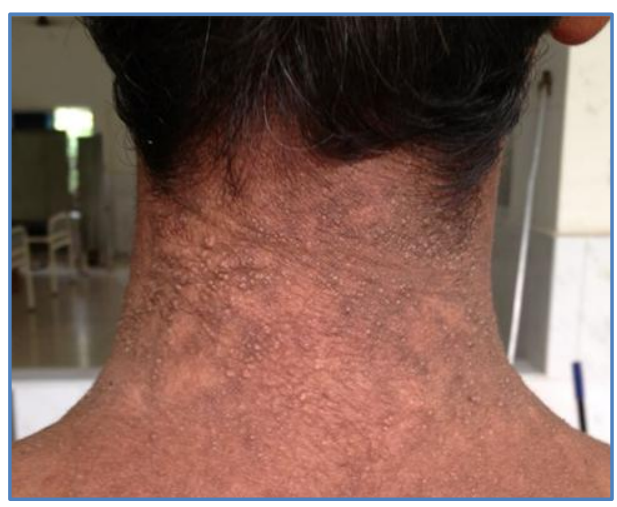

Fig. 3

Complete blood count, renal and liver function tests were within normal limits. X-ray of skull and CT Brain was normal. Videolaryngoscopy revealed nodules over the right ventricle and mobile vocal cords. Skin biopsy showed thickening \& elevation of papillary dermis, deposition of eosinophilic amorphous material surrounding capillaries \& sweat glands (Figure 4). Eosinophilic material was positive for PAS (Figure 5) and negative for amyloid. IQ assessment showed borderline intelligence.

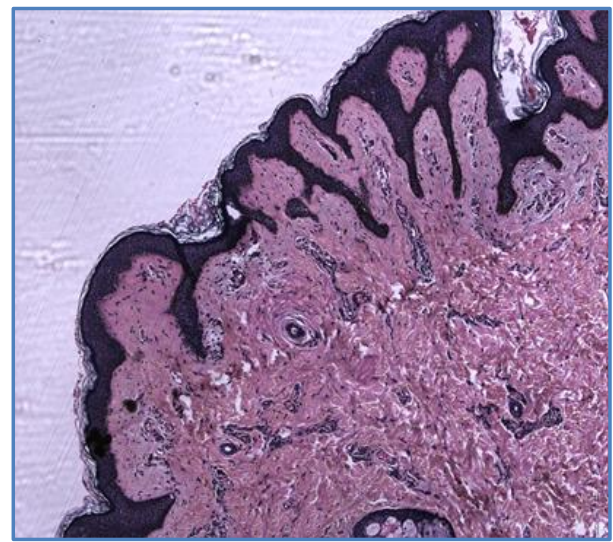

Fig. 4

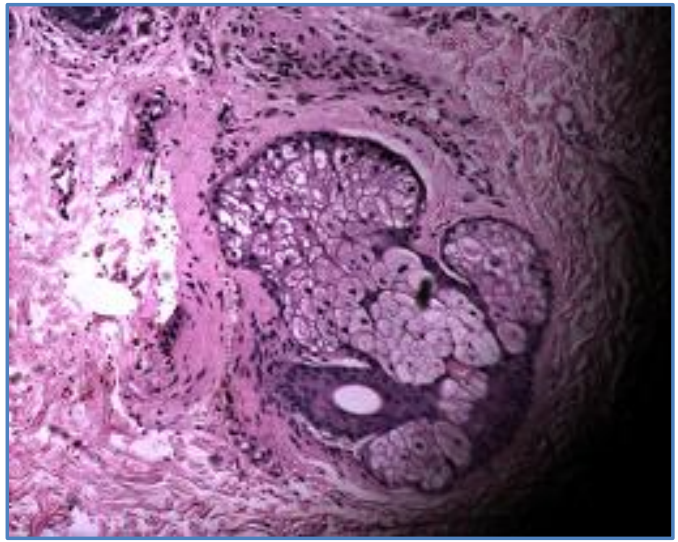

Fig. 5

Patient was started on capsule isotretinoin $20 \mathrm{mg}$ daily with regular monitoring of liver function test, fasting lipid profile and is undergoing speech therapy.

DISCUSSION: Lipoid proteinosis, a rare autosomal recessive disorder is common in the Namaqualand region of South Africa. ${ }^{3} \mathrm{~A}$ few cases have been reported in Indian literature. ${ }^{4,5,6}$ It is caused by mutations in the extracellular matrix protein 1 gene. ${ }^{7}$ Moniliform blepharosis (beaded papules) along the margins of the eyelids are characteristic feature. 
Other features include restricted tongue movement, hoarseness of voice, acneiform pock-like scars over the face, warty plaques over the dorsa of hands, palms, forehead, elbows. Alopecia, epilepsy, intra-cranial calcifications may also be associated. ${ }^{1}$ Involvement of viscera has also been reported. ${ }^{8}$ Histopathology revealed PAS positive hyaline deposition in the dermis, around blood vessels and sweat glands. ${ }^{1}$

Even though treatment of lipoid proteinosis is unsatisfactory, dermabrasion, chemical peeling, carbon dioxide laser therapy may be helpful. Oral dimethyl sulphoxide, etretinate and penicillamine are also beneficial. ${ }^{1}$ The disease can affect the quality of life and also requires a regular follow-up to detect resultant systemic complications.

\section{REFERENCES:}

1. Black MM. Lipoid proteinosis; Metabolic and nutritional disorders. In: Champion RH, Burton JL, Burns DA, Breathnack SM, eds. Textbook of Dermatology. 8th ed. Oxford, England: Blakcell Science, 2010: 59.41-59.42.

2. Dogramaci AC, Celik MM, Celik E, Bayarogullari H. Lipoid proteinosis in the eastern Mediterranean region of Turkey. Indian J Dermatol Venereol Leprol 2012; 78: 318-22.

3. Hougenhouck-Tulleken W, Chan I, Hamada T et al. Clinical and molecular characterization of lipoid proteinosis in Namaqualand, South Africa. Br J Der- matol2004; 151: 413-23.

4. Shah MK, Shah PP, Rawal RC, et al Lipoid proteanosis. Indian J Dermatol Venereol Leprol 1996; 62: 375-376.

5. Kaur V, Singh G. Lipoid proteinosis. Indian J Dermatol Venereol Leprol 1992; 58: 399-400.

6. Bansal NK, Mathur GK, Lipoid proteinosis Indian J Dermatol Venereol Leprol 1982; 48: 209212.

7. Hamada T, McLean WH, Ramsay $M$ et al. Lipoid proteinosis maps to $1 \mathrm{q} 21$ and is caused by mutations in the extracellular matrix protein 1 gene (ECM1). Hum Mol Genet 2002; 11: 833-40.

8. Caplan RM. Visceral involvement in lipoid proteinosis. Arch Dermatol1967; 95: 149-55.

\section{AUTHORS:}

1. Chetana Panabaka

2. M. Krishnakanth

3. Mahalakshmi V.

4. Anandan S.

5. Sudha R.

\section{PARTICULARS OF CONTRIBUTORS:}

1. Resident, Department of Dermatology, Sri Ramachandra University.

2. Assistant Professor, Department of Dermatology, Sri Ramachandra University.

3. Professor, Department of Dermatology, Sri Ramachandra University.

4. Professor, Department of Dermatology, Sri Ramachandra University.
5. Professor and HOD, Department of Dermatology, Sri Ramachandra University.

\section{NAME ADDRESS EMAIL ID OF THE CORRESPONDING AUTHOR:}

Dr. Chetana Panabaka,

H. No. 5/6, No. 11,

Southern Shelters,

Kattupakkam, Chennai-500036.

Email: p_chetana@yahoo.com

Date of Submission: 05/09/2014.

Date of Peer Review: 06/09/2014.

Date of Acceptance: 17/09/2014.

Date of Publishing: 25/09/2014. 